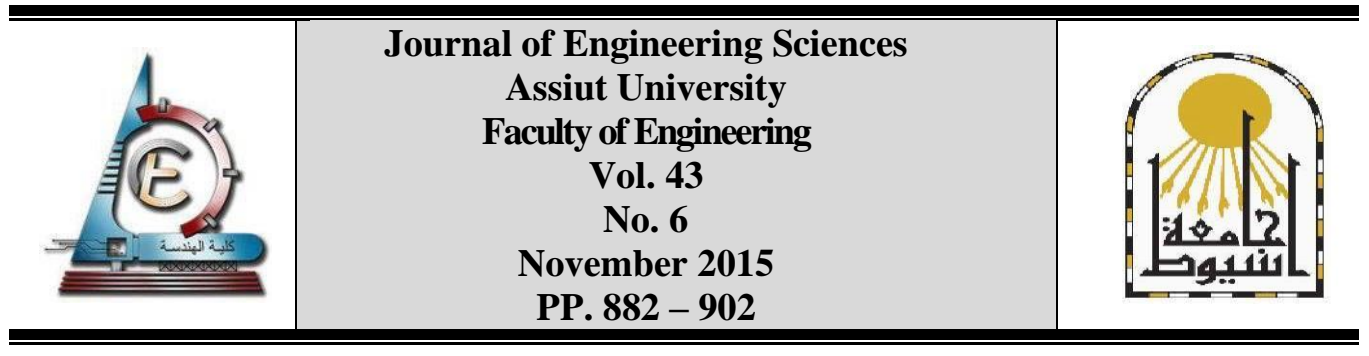

\title{
TOWARDS A SUSTAINABLE DEVELOPMENT OF DAMIETTA: AS A COASTAL INTERMEDIATE CITY IN EGYPT
}

\author{
Ahmed Yehia Mohamed Gamal E-Idin Rashid ${ }^{1}$, \\ Mona Awad Abo El-Anin ${ }^{2}$, Walaa Abd Al-Razik ${ }^{3}$ \\ ${ }^{1}$ Department of Architecture, British University \\ ${ }^{2}$ Department of Architecture, Mansoura University \\ ${ }^{3}$ Architect
}

(Received 13 July 2015; Accepted 8 August 2015)

\begin{abstract}
Damietta[1] is a port and the capital of the Damietta Governorate in Egypt. It is located at the Damietta branch, a distributary of the Nile, (latitude $31^{\circ} 25^{\prime} \mathrm{N}$, longitude $31^{\circ} 49^{\prime} \mathrm{E}$ ). Damietta is located at the Damietta branch, a distributor of the Nile, 15 kilometer (9.3 mi) from the Mediterranean Sea, about 200 kilometers (120 mi) north of Cairo. [2]

The intermediate cities are considered to be one of the cities that had a vital and powerful foundation in establishing a significant economic and social interaction. Damietta is classified as an intermediate city (according to UIA-CIMES program) that has costal environments with great economic value. This Paper aims to highlight the features of sustainable development to prospers coastal intermediate cities and provide plans and new approaches to be applied to its counterpart, then to predict the rates of urban development in order to control the direction of sustainable urbanization in intermediate cities.

All of these issues were studied previously from the theoretical point of view that deals with the concepts related to the research problematic, and reviewed it through an analytical study of the city represented in Damietta city as a coastal intermediate city on the coast of the Mediterranean Sea, to come with an analytical research ended with results $\&$ recommendations.
\end{abstract}

Keywords: sustainable development - Intermediate cities - coastal cities - Coastal Area - Damietta city.

\section{Introduction}

Intermediate cities are considered to be one of the cities characterized by having a vital and powerful foundation in establishing a strong economic and social interaction which plays an important role in connecting small and mega cities to each other through a regional network with one of their characteristics. This point is the most important one and should be taken into consideration when developing intermediate cities, because it represents adynamo engine for huge development elements. When the historical background of the cities

\footnotetext{
* Corresponding author.

Email address: walaa.a.elrazik@gmail.com
} 
was added to the pervious point, in addition to other features of intermediate cities, this will increases the inevitable development and maintenance of those cities.

The Paper investigates Damietta, which is an intermediate city that has costal environment with significant economic value as part of (CIMES) [3] Program for intermediate cities held by UIA Organization. When the historical background characteristics of this city are taken in consideration, it will be clear the Urban and Regional influence of this city, which is considered to be a distinguished one according to its location, and this influence plays a vital role in sustainable development of this city and its urban territories, as well as it significantly impacting on the direction of urban development. On the other hand coastal intermediate cities suffer from lack of implementation mechanisms and directions of its sustainable development; there for this Paper presents a question relating to that issue "Is it possible to achieve a sustainable development of Damietta as coastal intermediate City?" The Paper aims to obtain features of the sustainable development prosperity for coastal intermediate cities, then investigates the possibility to reach a new methodology that could be applied to counterparts cities, and then predict development rates of construction in order to control the direction of sustainable urbanization in intermediate cities, in order to achieve the objectives of this paper, we have to provide a hypothesis to be tested through the study, which represents the way to reach the results that will be discovered in this Paper which states : Sustainable development of coastal intermediate city can be achieved by a specific strategy based on the studies on the nature of the city and application, that has been done through a demo of some definitions and concepts that have been studied through the theoretical part such as : The concept of Sustainable development and its objectives, characteristics of its operations, its interlocutor, and its fields. Then recognize intermediate cities in terms of its concept through the UIA-CIMES Project, its definition, its important characteristics, and identifying concept of coastal cities. As the paper reviews the concept of the sustainable development of coastal intermediate cities through the hypotheses of sustainable development plan for Damietta city, the challenges it faces, and its advantages ecosystems, and the principles of sustainable development for it, its strategy, then the Paper reviews through the analytical part study of Damietta as a model for intermediate cities sited on the Mediterranean Sea, then reaching the results and finally set the recommendations.

\section{Sustainable development}

\subsection{The concept of sustainable development}

The origins of the sustainable development concept have been seen to lie in two bodies of literature. These are 'development thinking' and 'environmentalism' which were quite separate previously. Within the notion of sustainable development, the vision of the two areas of study came closer together with the realization that environment and development were interdependent and mutually reinforcing issues. Development is no longer seen in exclusively economic terms. The view now indicates that we need to conserve in order to develop, rather than the reverse[4]. Sustainable development as a concept aims to resolve the environmenteconomic- social conflicts by portraying itself as a multi-dimensional concept, which perceives environmental, social and economic objectives in an integrated way. This is what was missing in previous strategies, which seemed to overemphasize on the economic dimension of development and gave no attention to addressing the cost of the environmental dimensions.

The community has many links with the three systems, if the development strategy deals with the community as if it was made of three separate parts, they 
Walaa Abd Al-Razik et al., Towards a sustainable development of Damietta: as a coastal .........

don't overlap as shown in Fig 1. The community problems in this case are viewed as isolated issues; solving one problem can make another problem even worse.

Therefore, the three systems should be viewed as related parts which are connected, dependent upon each other, therefore, to solve community problems we should take into consideration the links among its three parts: the economy, the environment and the society[5]. Fig 2.

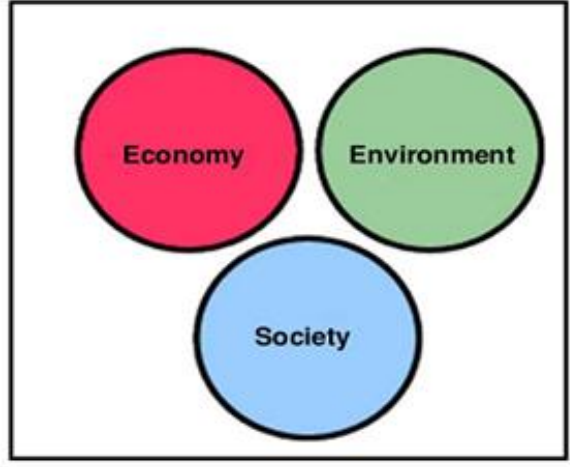

Figen 1. A diagram illustrating the three dimensions of sustainability as separate parts Source: Source: Sam C. M. Hui. (2002)

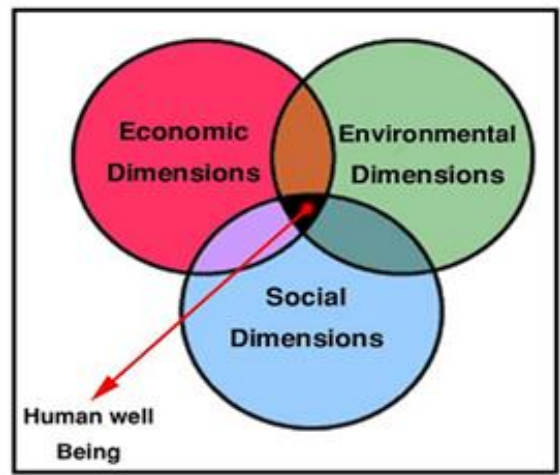

Fig, 2. A diagram illustrates the three dimensions of sustainability as related parts. Source: Source: Sam C. M. Hui. (2002)

\subsection{Definition of sustainable development}

Sustainable development is known as development which works on optimum exploitation for available resources in developing projects without the need of depletion of other resources which becomes a must for the continuation of those projects[6],

So sustainable development is the development, which meets the present necessities without prejudice the ability of future generations to obtain their needs [11]. Some international reports has indicated some aspects that have been agreed upon regarding the concept of sustainable development, so some of them focused on the Physical Aspects in sustainable development and pointed out that sustainable development is the one which emphasizes on the use of natural renewable resources in a way which doesn't lead to the extinction or degradation or diminishing their usefulness for future generations while preserving the balance of the fixed non-decreasing natural resources such as "Soil - and groundwater - and biomass[7],

Other reports also focused on the Economic Aspects of sustainable development operations which Emphasizes that the process of sustainable development should focus on the optimal management of resources to get the maximum benefits of economic development, provided to maintain the quality of natural resources and that the usage of the resources must not detract the real income in the future[8], also others focused on the Environmental Aspects which noted that the sustainable development is the one uses a cleaner new technology, more efficient and better ability to save natural resources in order to reduce pollution, help to stabilize the climate, and accommodate growth in population[9].

\subsection{Objectives of sustainable development}

Sustainable Development Operations aims to the following[10]: -

- Achieve healthy and productive life for mankind.

- Achieve social justice and promote gender equality and empower women. 
- Ensure sustainable environment and to provide the right for future generations in natural resources and wealth through the rational use without extravagance or waste.

- Raise the standard of living for individuals and eradication poverty.

- Popular participation in developing policies, reviewing it and in decision-making.

- Establish a global partnership for development.

\subsection{Sustainable development's dimensions}

Although some which still argue that economics is primary, and culture and politics should be included in 'the social'. This document inaugurates a new perspective and points to the relation between culture and sustainable development through a dual approach: developing a solid cultural policy and advocating a cultural dimension in all public policies. The Sustainability approach distinguishes the four domains of economic, ecological, political and cultural sustainability. [11], [12]

Other organizations have also supported the idea of a fourth domain of sustainable development. The Network of Excellence "Sustainable Development in a Diverse World",[13] sponsored by the European Union, integrates multidisciplinary capacities and interprets cultural diversity as a key element of a new strategy for sustainable development.

The Fourth Pillar of Sustainable Development Theory has been referenced by executive director of IMI Institute at UNESCO Vito Di Bari[14] in his manifesto of art and architectural movement Neo-Futurism, whose name was inspired by the $1987 \underline{\text { United Nations' report Our }}$ Common Future. The Circles of Sustainability approach used by Metropolis defines the (fourth) cultural domain as practices, discourses, and material expressions, which, over time, express continuities and discontinuities of social meaning. [15]

Working with a different emphasis, some researchers and institutions have pointed out that a fourth dimension should be added to the dimensions of sustainable development, since the triple-bottom-line dimensions of economic, environmental and social do not seem to be enough to reflect the complexity of contemporary society. In this context, the Agenda 23 for culture and the United Cities and Local Governments (UCLG) Executive Bureau lead the preparation of the policy statement "Culture: Fourth Pillar of Sustainable Development", passed on 17 November 2010, in the framework of the World Summit of Local and Regional Leaders - 3rd World Congress of UCLG, held in Mexico City.

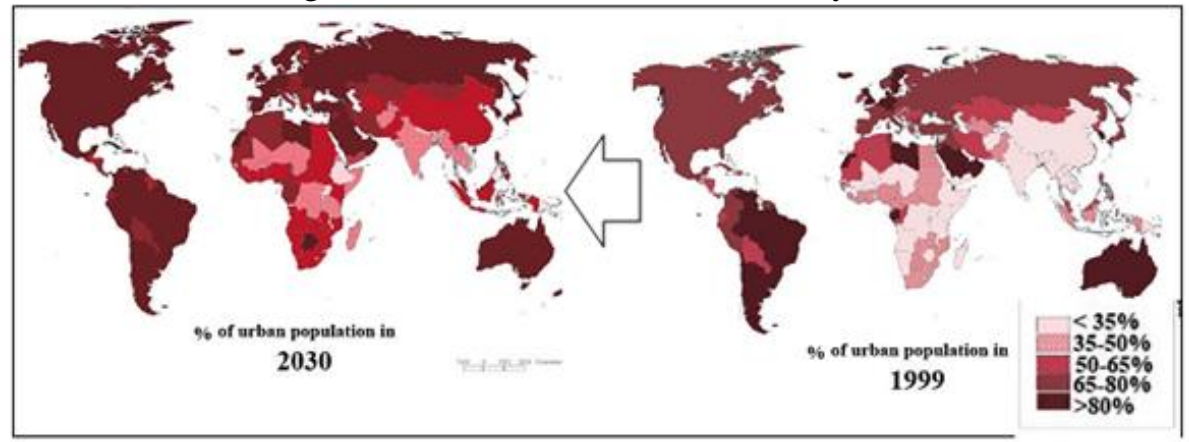

Fig. 3. the percentage of urban population to the population in the different World's states in 1999 and 2030 - Source: Llop, J. M \& Bellet, C (2002)," Intermediate Cities. Profiles And Agenda," UIA-CIMES work programme. 
Walaa Abd Al-Razik et al., Towards a sustainable development of Damietta: as a coastal .........

\section{Intermediate cities}

Intermediate Cities offer rural population a better living conditions, jobs in a less polluted environment, and act as local markets for their products. They also provide services and a collective infrastructure, not only to the urban but also to the rural and regional population. In some regions, generally within more industrial areas or close to large cities, many smaller urban centers have succeeded in attracting new investments that previously would have tended to concentrate in large cities. [16] See fig 3.

The majority of the world's urban population lives in small and medium-sized cities, which are also notably more numerous. According to the previously cited source, $62.5 \%$ of the world's urban population resides in cities with fewer than one million inhabitant[17]

According to the United Nations (UNCHS 2001), in the year 2000, the world population was 6.05 billion, of which $47 \%$ lived in an urban environment $(76 \%$ in the western industrialized countries, as against only $39.9 \%$ for the totality of developing countries). This rise is bound of continue reaching $53.4 \%$ in 2015 for the plant as a whole (see table 1).However, the most important aspect of this accelerated urbanization process is that it is by no means uniform, It differs depending on the world region and type of city. All in all, one can say that urban growth affects primarily the developing world (3.6\% annual growth rate between 1975 and 2000 aganist2.5worldwide) [18].

Table 1.

The Percentage of population living in urban in urban areas and average annual rate of growth by major area. Source: Data form UN (2002), UNCHS (2001.)

\begin{tabular}{|l|c|c|c|c|c|}
\hline & \multirow{2}{*}{$\mathbf{2 0 0 0}$} & \multirow{2}{*}{$\mathbf{2 0 1 5}$} & \multirow{2}{*}{$\mathbf{2 0 3 0}$} & \multicolumn{2}{|c|}{ Urbanisation rate of Growth (\%) } \\
\cline { 5 - 6 } & & & & $1975-2000$ & $2000-2015$ \\
\hline World & 47.0 & 53.4 & 60.3 & 2.5 & 2.0 \\
\hline More Developed Regions & 76 & 79.7 & 83.5 & 0.8 & 0.4 \\
\hline Less Developed Regions & 39.9 & 48.0 & 56.2 & 3.6 & 2.6 \\
\hline Latin America and Carbbean & 75.3 & 79.9 & 83.2 & 2.7 & 1.7 \\
\hline
\end{tabular}

\section{Intermediate cities definitions typology}

The definitions vary. The most common definition is that of a city with a population of 20.000 up to 200.000 , depending on population density and the perspective urban system in a country[19].Such city usually have mixes of supply, development, and relief functions for the region in which they are geographically embedded. If located at an inner-European border or at the edge of the European Union they may also have an additional function as an exchange or gateway function. Medium-sized cities can be cities[20]:

- With in larger metropolitan regions,

- On the edge of or in between metropolitan regions,

- In the geographical periphery of Europe.

\section{Coastal cities}

Coastal areas with the historical content are the most populated regions of the world which emphasizes the importance of preservation and development of various resources. 
The characterization of historic coastal cities is emphasized by the characteristic aspects of the place, the natural content; this is on one hand, the fragrance of history and the physical humanitarian output on the other. These aspects are added to the visual, materialand functional values formed part of an integrated which distinguishes these cities. Because of the importance of these cities, they need to have conscious policy to deal with its potentials rather than to be wasted and lost. That policy should aim to stimulate the economic development of these cities through a series of changes and direct transformations.

Some of Coastal Cities required renewing it by protecting the vital, economic, social content and environmental resources and activities and of these cities also its inhabitants. It is founded that the coastal areas of historical value are distinct environments in the urban fabric and has many possibilities and different from than the non-coastal areas. These areas that have the same physical and natural fabric

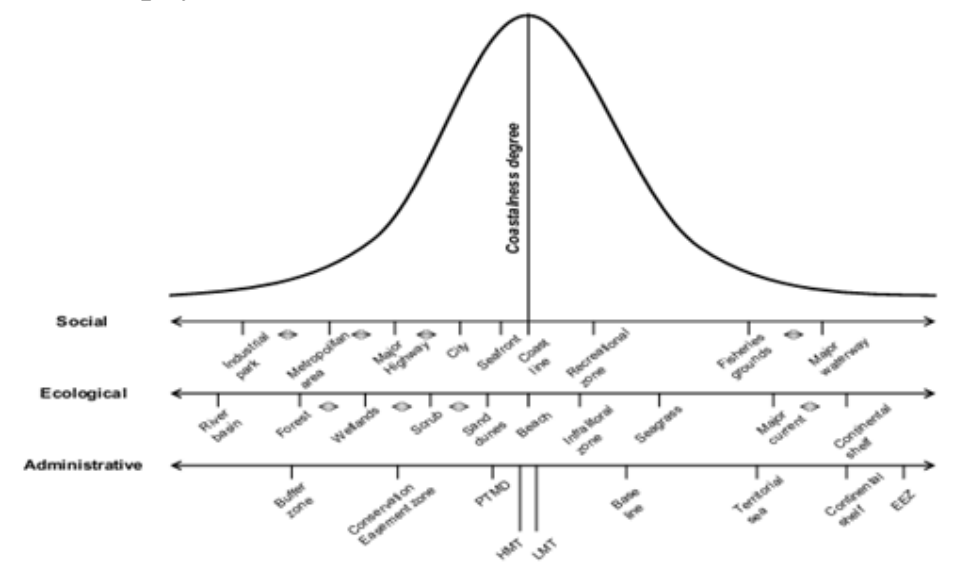

Fig. 4. Coastalness degree of some elements of the social and ecological subsystems (Adapted from Kay and Alder 2000).

\subsection{Definition of coastal environments}

Both the terms coast and coastal are often used to describe a geographic location or region; for example, New Zealand is West Coast, or the East and West Coasts of the United States [21]. The coastal region is a region where the sea and land interact significantly which creates large surface of this region, which is known as the area lies between the axis extending along the coast and the vertical axis on the line of the coast[22].

A coastal zone is defined as "Lands and waters adjacent to the coast which could be affected by the uses of the sea and its ecology, or whose uses and ecology are affected by the sea." [23]

It was found that a coastal area contains land connected to the sea as well as the Coastal space connected to the land, and thus it contains:

1. It's Components of sea and land.

2. The limits of sea and land, which are determined by the degree of influence that Land exerts over the sea as well as the impact of the sea on dry land.

3. The coastal zone has no Unified length, width, or depth. 
Walaa Abd Al-Razik et al., Towards a sustainable development of Damietta: as a coastal .........

The above three elements are depicted in Fig 4-1 which shows a sandy beach coast, the strength of interaction between coastal and sea processes and uses ,termed here the degree of coastlines, against the distant away from the immediate coast.

\subsubsection{The Egyptian coastal zone}

The coastal zone may be defined according to ecological, socio-economic, political or legal criteria or any combination of these. The same factors can also be used to determine the extent and boundaries of a region, sector, or other geographical unit. The National Committee has adopted the following definition for the coastal zone for ICZM [24]:

The coastal zone is a domain of land-sea interface. It encompasses the territorial water and extends landwards to areas of active interaction with the marine environment for at least $30 \mathrm{~km}$ in the desert areas, unless major topographical features interrupt this stretch, while in the lower Nile Delta region the terrestrial part would extend up to the $3.0 \mathrm{~m}$ contour above sea level[25].

\section{Sustainable development of coastal intermediate cities}

A plan of sustainable development of coastal intermediate cities had been made in several points that should be considered its hypothesis, and the challenges that faces those cities, and ecological benefits of them, and then determine the principles of development and development strategies, the research represent to those points as follows:

a) Principles of sustainable development for intermediate cities [26]:

- The development of intermediate cities should be locally conceived and not imposed from outside.

- The development of intermediate cities should be based on the sustainable use of their resources.

- The development of intermediate cities should provide for basic necessities, ensure secure living conditions and promote equity

- The development of intermediate cities should foster empowerment, encourage greater local control over resources, and promote the participation of the marginalized and under-represented.

\section{b) The criteria for sustainable development in intermediate cities should be:}

- A form of development which causes irreparable damage to either the natural or planetary system, avoids the use of non-renewable resources, pollutes and makes efficient use of energy.

- A form of development that considers the community when it comes to taking decisions, that destroy social structures, offers no risk to health, and reduce quality of life.

- A form of development that reduce the value of property that diversifies the community's sources of income, and provides job opportunities.

- The aforementioned principles and criteria can, and should, be used as a basis for establishing a series of guidelines and objectives that can be personalized in response to the particular circumstances of each time, place and culture in which development occurs. 


\section{c) The challenges of Coastal Intermediate Cities:}

- Globalization and its impact on the coastal intermediate city: through the multiplicity of local resources, as intermediate coastal cities can contribute in solving the relevant issues by confirming its own identities.

- Regulate the relationship between those cities and their neighbors: intermediate cities could organize their relationship to coastal areas and the neighboring cities by improving the ways they are connected to other cities abroad and also by the rationalization of the transportation systems.

- Developing new forms of movements within it: by taking advantage of features provided by its size and location on the Mediterranean coast and beaches.

- Provide economic and human solutions: costal intermediate cities could provide more diverse and integrated solutions into the framework of their perimeters and extent of economic spatial and its own human resources.

\section{Strategy for the sustainable development of coastal intermediate cities}

Strategy development of the coastal intermediate cities is based on a variety of considerations [27]:

- Achieve the growth balance among the various economic sectors (industry Agriculture - Tourism - Fishing - -...... mining, etc.) in all study areas according to productive resources

- Identify the expansion potential in diversity of economic base and strengthen it for various units territorial affecting the cities of research to ensure the continuity of the process of regional development

- Integration between urban communities affecting to coastal intermediate cities and the impact on each other.

Based on the foregoing, the elements of strategy for the sustainable development of coastal intermediate cities are as follows:

- Take advantage of the available elements of development on the coast

- Linking the functions of urban communities (urban and rural) with the communities Capabilities (location - back urban - population size - the availability of development economics - service centers - the efficiency of infrastructure - Urban absorption....)

- Dividing the city to developing units which seems homogeneous as these units should have the ability to interact between each other besides their neighbors and those cities that affect it [28]

Thus, the strategy fields of sustainable development for coastal cities as the four factors follows:

\section{- In the field of inhabitedness Cities:}

- Development of current urban structure and consistent with the absorptive capacity of urban communities of the city.

- Provide opportunity of growth for the city depending on the possibilities of its development.

- Expand the chain of urban centers that serves rural areas in different levels of the city. 
- Show interest to provide a basic services and infrastructure of Housing in field of tourism and Hostelry which revive the coastal tourism and fishing which support city activities.

- Provide opportunity of growth for the city depending on agriculture and fishing which will expand the city urban communities.

\section{- In the field of roads and transportation:}

- Support road transport movement from city ports to surrounding cities with secured highways

- Show interest to provide a basic services and infrastructure that leads to provision of integrated community and to make a new urban community, not only to be an industrial one, or a trade zone alone.

- Provision of utilities (electricity - water - roads - communication).

- In the field of the economy:

- Reduce unemployment.

- Economic development is characterized by being a multi-faceted one, therefore any activity of the existing activities can have its own unilateral sovereignty over economic development, it is possible that economic development depends on agriculture, industry or crafts or tourism etc.

- Support of complementary activities related to basic activities such as cargo business and branching in order to encouraging investment in such activities, including establishment of tourism activity, such as construction of hotels\& restaurants besides other tourism services.

- Support activities related to maritime exchange trades for example export, import, marine transportation and marine services and ports which are the administrative and commercial city center.

\section{- In the field of industrial development:}

- Raise industrial growth rates

- Depending on various industries. Small-scale industries are the most important, and adopting light industries

- Link industry with the local market \& the needs of population[29]. 


\section{An analytical study of Damietta city}

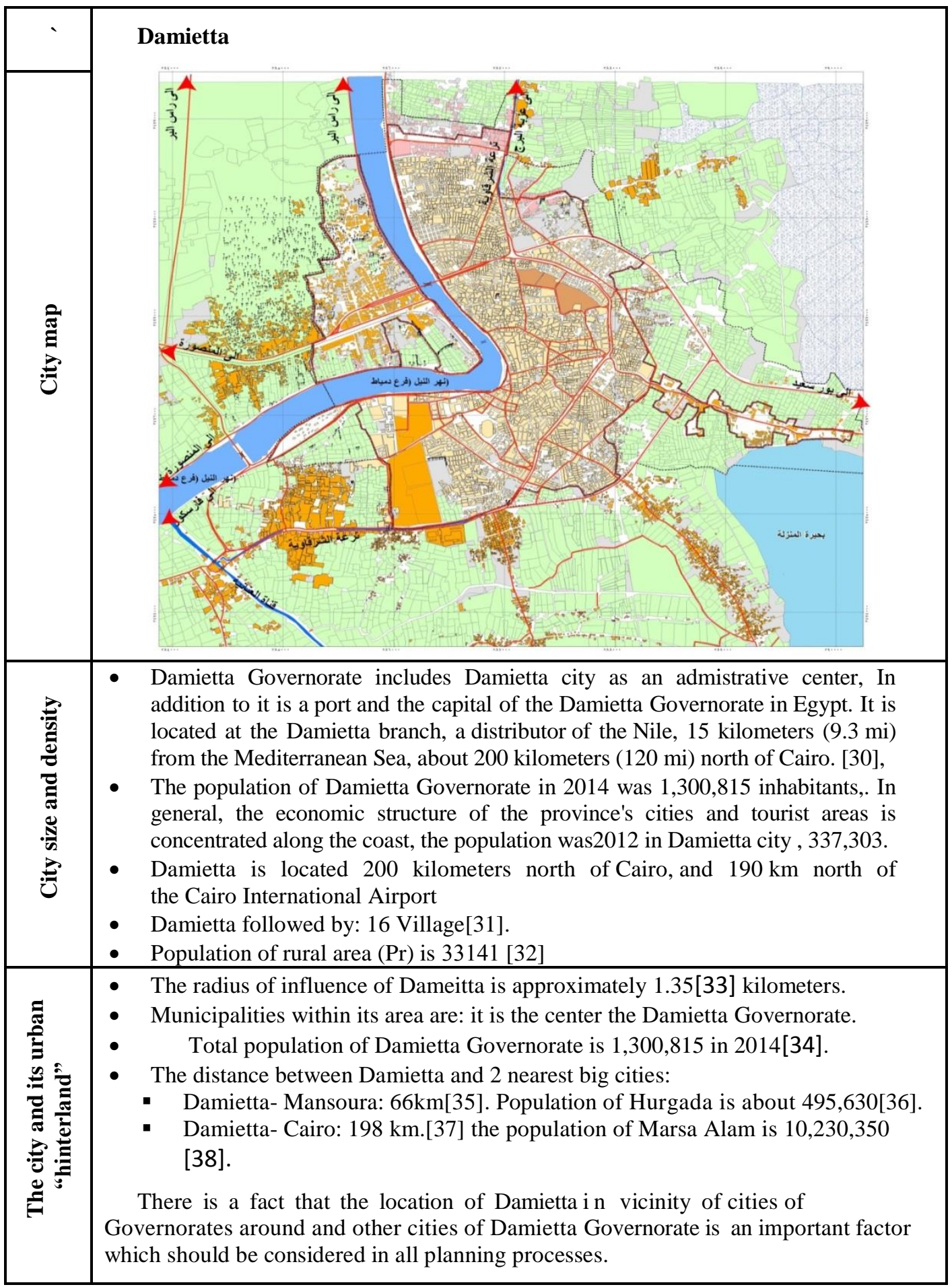


Walaa Abd Al-Razik et al., Towards a sustainable development of Damietta: as a coastal .........

\begin{tabular}{|c|c|c|}
\hline 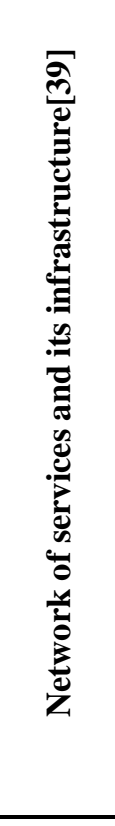 & \multicolumn{2}{|c|}{$\begin{array}{l}\text { - The city relies on sources of drinking water purification station in main city and } \\
\text { that their approach Nile River station, which produce daily average of } 22800 \\
\text { m3per day. Due to the increasing needs of the city from the water, it is } \\
\text { strengthening the water network in the city of Al Bustan purification station } \\
\text { with a total of } 4800 \mathrm{~m} 3 \text { / day. } \\
\text { - Water Station Damietta feed Damietta City and the surrounding areas and out } \\
\text { of the station sthree main lines of two } 12 \text {-inch and } 16 \text {-inch and another is fed Al } \\
\text { Bustan water station, } 20 \text {-inch diameter line with average daily consumption per } \\
\text { person } 1 . d \text { liters / day. } \\
\text { - There are } 24 \text { sub-station lifting in addition to the main central station, which } \\
\text { covers the needs of the city, and there are processing unit capacity of } 60,000 \\
\text { m3 / dayPublic lighting and electrical grids cover approximately all the urban } \\
\text { surface area. } \\
\text { - Sewage is disposed of in the slums on the edge of the city and using septic } \\
\text { tanks and septic tanks. Sewage network covering about } 98 \% \text { of the city. } \\
\text { Total capacity of electricity of } 166 / 11 \mathrm{~K} . \mathrm{V} \text { and the capacitiy per person } \\
211 \mathrm{~V} . \mathrm{A} / \text { person } \\
\text { Frequency of street cleaning is daily. } \\
\text { Refuse recycling in Damietta is almost new and it's in the process by } \\
\text { participation of one factory. }\end{array}$} \\
\hline & \multicolumn{2}{|c|}{$\begin{array}{l}\text { - Nearest airports located in Cairo International airport is far 190.[40] } \\
\text { - There is a rail station in Damietta. } \\
\text { - Public transportation in Damietta includes bus and minibus mainly to the } \\
\text { direction of other cities and also to other destinations. } \\
\text { - Public transportation inside the city is done by bus and minibus. Also there is } \\
\text { public taxi with a specified origin and destination with } 4 \text { passenger capacity. }\end{array}$} \\
\hline 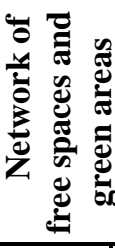 & \multicolumn{2}{|c|}{$\begin{array}{l}\text { To identify the percentage of the urban surface that is not destined for } \\
\text { construction, boundaries for nine different Watercourses and the shore could be } \\
\text { calculated as free spaces which are not allowed to build. Public Green and open } \\
\text { spaces areas including parks around and inside the city are 17.17Acre, and the free } \\
\text { places around and inside the city are } 464.95 \text { Acre, [41]. }\end{array}$} \\
\hline \multirow[t]{2}{*}{ 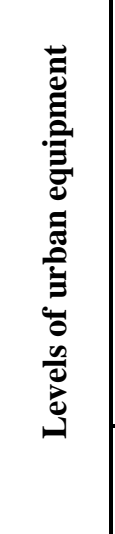 } & $\begin{array}{l}\text { Socio-cultural } \\
\text { structure }\end{array}$ & $\begin{array}{l}\text { Education rates have seen a marked increase in Egypt, the } \\
\text { oroportion of adults educated Has increased over } 15 \text { than (reading and } \\
\text { writing level) of }(25.8 \%) \text { in } 1960 \text { to } 65 \% \text { in } 2001 \text { [42].Education data } \\
\text { hows over twenty years from the direction of a similar large } \\
\text { mprovement seen in the low literacy rates and high school secondary } \\
\text { education and by } 2001 \text {,education ratios reached that rate starts level } \\
\text { literacy) in Damietta to } 70.1 \% \text { and illustrate evidence in the } \\
\text { levelopment program of the United Nations. That differences in } \\
\text { iteracy rates between centers are significant differences between the } \\
\text { center and the city of Damietta, about } 82.7 \%\end{array}$ \\
\hline & Health care & $\begin{array}{l}\text { specialized hospitals, and two General } \\
\text { he city }\end{array}$ \\
\hline
\end{tabular}




\begin{tabular}{|c|c|c|}
\hline 苞 & \multicolumn{2}{|c|}{$\begin{array}{l}\text { The type of government of Egypt is central. There is } 27[43] \text { provinces and each } \\
\text { province has a governor also each county has one local governor. Damietta Governorate } \\
\text { has a governor who works as responsible body for management of territory including } \\
\text { the urban and rural areas. } \\
\text { There is a City Council with numbers of councilors who elected by citizens. It chooses } \\
\text { the Mayor of the city and approves developing projects for the city and supervises the } \\
\text { Municipality's activities. Municipality of Damietta as a part of Damietta government is } \\
\text { responsible to manage urban problems and development. }\end{array}$} \\
\hline 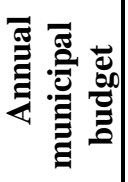 & \multicolumn{2}{|c|}{$\begin{array}{l}\text { The budget of municipality comes from government to the mayor of the city. It is } \\
\text { separated in } 2 \text { parts: projects and current management costs. In the municipal budget law, } \\
60 \text { percent is defined for civil and development projects and } 40 \text { percent of that is predicted } \\
\text { for the current issues including maintenance and municipal issues. }\end{array}$} \\
\hline خ & \multicolumn{2}{|c|}{$\begin{array}{l}\text { Considering the great effect of Damietta on its surrounding cities, and } \\
\text { relations between it and Mansoura could be said that Damietta is a medium-sized city. } \\
\text { But on the other hand, Damietta has its own economic activities especially in Furniture } \\
\text { Industry and fishing. }\end{array}$} \\
\hline \multirow{2}{*}{ 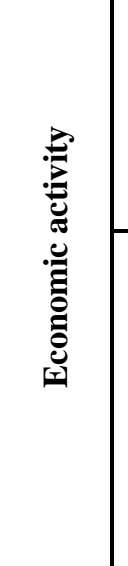 } & $\begin{array}{r}\text { Employm } \\
\text { ent structure }\end{array}$ & $\begin{array}{l}\text { Employment structure by the division between primary } \\
\text { (Industry), secondary (A Commerce) and tertiary sector (Fishing \& } \\
\text { agriculture) is shown in the chart below. Based on Statistical } \\
\text { Manual, there are } 7344 \text { employments in direct relation with } \\
\text { Industry which means } 38.30 \% \text { of total population[44]. }\end{array}$ \\
\hline & $\begin{array}{c}\text { Rate of } \\
\text { unemployment }\end{array}$ & $\begin{array}{l}\text { Based on the Statistical Manual of Damietta Governorate in } 2014 \text {, } \\
\text { the rate of unemployment except housewives and students is } \\
\text { approximately } 8.4 \% \text {.[45] } \\
\text { The major economic problems that have emerged in cities with } \\
\text { high and low intensity are Input high unemployment, low income } \\
\text { families, focusing deprivation, Reduction of Public services, } \\
\text { infrastructure services and environmental degradation is decreased. }\end{array}$ \\
\hline : & \multicolumn{2}{|c|}{$\begin{array}{l}\text { The total numbers of Families in Damietta city are 53790[46] which based on the } \\
\text { population of City of Damietta. } \\
\text { - There are not a considerable number of homeless people. } \\
\text { - All the urban area covered by electricity network. }\end{array}$} \\
\hline
\end{tabular}


Walaa Abd Al-Razik et al., Towards a sustainable development of Damietta: as a coastal .........

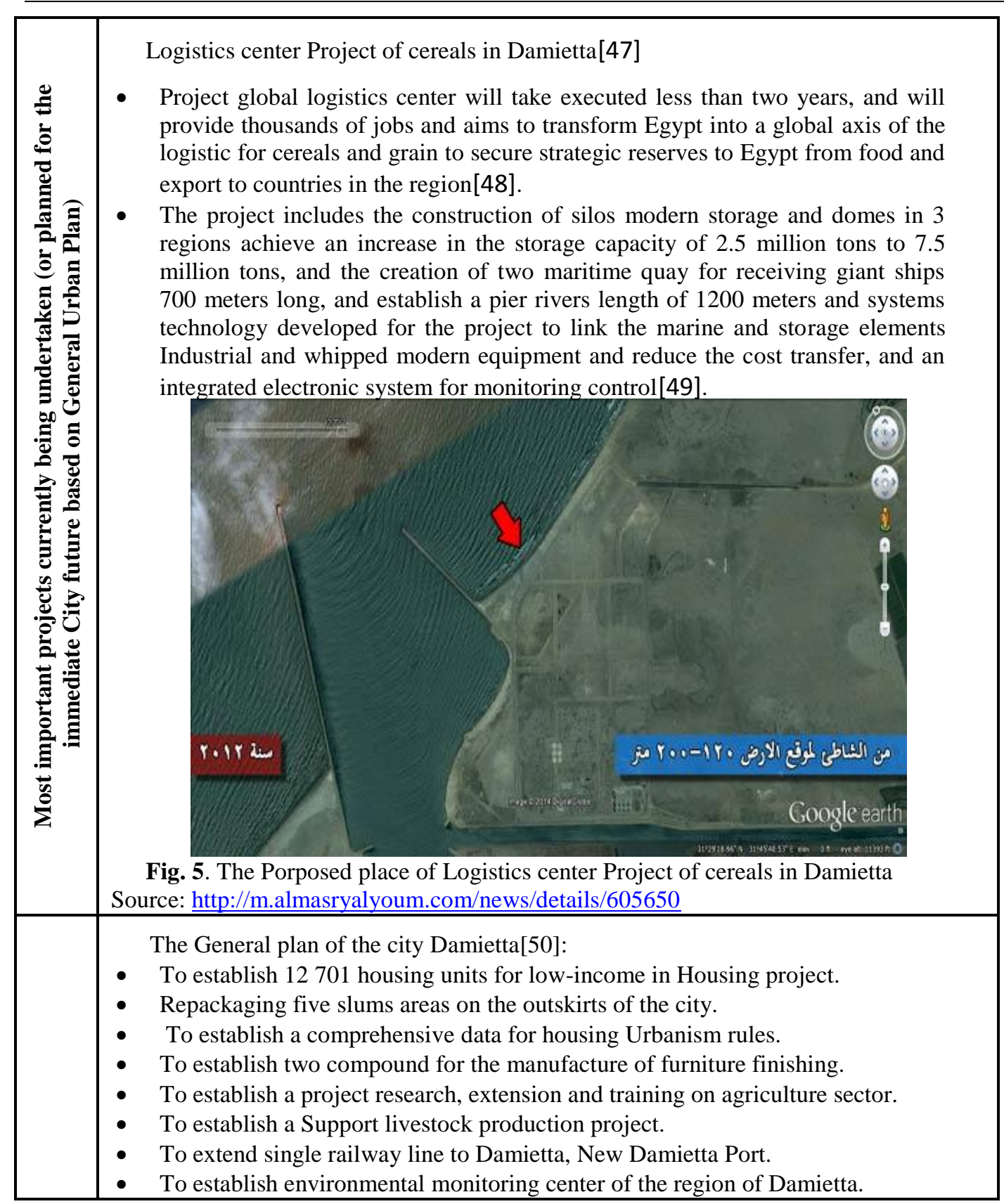

\section{Analytical results of the study}

From the previous analytical study, we concluded goals and objectives of sustainable development in Damietta as an example of the coastal intermediate city as follows:

\subsection{Introduction}

A strategy of development depends on the whole previous urban, economic, social studies and their interactions with other conditions of local, regional and international data Concurrently with the time of drafting that Strategy, thus the development and 
reconstruction strategy for Damietta city have benefited from the study concerning the strategy of development of Delta province, which ended to determine a range of orientations in regard of the development of cities in the region, including Damietta city In light of requirements of each city, guidelines has evolved, as follows:

- Identifying the residential area of urban communities and various means to control urban growth on the expense of agricultural land.

- Reduction of Urban inflation within the general perception framework of the Delta region and adjacent regions.

- Reconsider the relationship between new cities and the city under study and its relationship to the adjacent regions to the achieve development requirements to the regions with high densities.

\subsection{Objectives and pillars of development strategy of Damietta City}

\subsubsection{Objectives of development strategy of Damietta city}

- Reduce the population density and the exploitation of overpopulation in urban development in the desert, which leads to contribute the achievement of the Egyptian national goal which aims to increase urbanism in Egypt.

- Reclamation and cultivation of more land through available earth \& aquatic resources.

- Paying attention to tourism industry.

- Take advantage of the diversity of agricultural production in the Province with presence of the industrial environment to encourage the agro-industrial integration.

- Development of Labor-intensive Small-scale Projects and craft activities in the city to provide more jobs and reduce unemployment problem.

- The need to control urban extensions, which spread over agricultural land due to the intensification of population in the city.

- Take advantage of the cities' geographical position to increase exports.

- Work to reduce the illiteracy rate by some internal solutions along with popular participation.

\subsubsection{Pillars of development strategy of Damietta city}

- Contributing in the reduction of the food gap, especially crops of comparative advantage, through the expansion in cultivation of species and varieties of high productivity appropriate to the Conditions of the region.

- Paying attention to support human skills \& capabilities in order to raise the income levels and living standards for citizens.

- Provide incentives to the private sector so as to create a suitable climate for it to play its role in regarding the economic development.

- Pay attention to services in the province to improve the living and environmental levels

- Rationalizing the use of energy to face the increase in consumption.

- The concern to take necessary procedures to cope with sewage and industrial drainage problems because of its significant impact on waterways and groundwater and also its influence on both human health and agricultural activity. 
Walaa Abd Al-Razik et al., Towards a sustainable development of Damietta: as a coastal .........

- Show of interest to the productive capacity of the city to promote the living standards of citizens' income.

- Support communication networks between centers of the city and the new construction areas in west desert of Delta.

- Rationalizing the use of energy and the need to find means of development to confront the increase in consumption.

\subsection{Dimensions of the development strategy for Damietta City in Damietta Governorate}

When developing a strategy of development, the following considerations have to be considered:

- Achieve balance in growth between the various economic sectors as (industry agriculture - Tourism - fishing ...) in all development areas according to their productivity resources.

- Achieving balanced regional development between the sub-units regional of cities according to the size of the problems of each area and, accordingly on the quality of the resources available for each.

- To identify the potentiality for expansion of diversifying the economic base and strengthen of various regional sub-units that ensuring ongoing regional development process in each of the regional sub-unit.

- Identify growth centers (regional and local) serve as a framework to accommodate sectoral development efforts so that this urban centersurves as a tool for the adjustment urban balance at the level of the region.

9.4. Based on the determinants and as mentioned considerations, elements of development strategy in the city are as follows

- Take advantage of the development elements for the northwest coast of the new city of Damietta and new communities surrounding it (new villages), which have both economic base and population size related to the nature of these elements.

- Linking functions of urban communities (urban and rural functions) with the potentialities of these communities (location - population size - the availability of development economics - centrality of services - efficiency of basic environment - Urban Capacity ).

- Reduction of development in regional units' and urban communities which have lack balance between population and economic resources and available space for urban development.

- Dividing the city into development Centers characterized by harmony and the ability to interact between its parts.

\subsubsection{Fields of development strategy in the city}

Based on the foregoing, the following areas are identified for development of Damietta in Damietta Governorate:

(A) Fields of urbanism:

- The development of the current structure of urban in line with the absorptive capacity of the city

- Provide an opportunity for neighboring new cities for faster growth rates as it is expected to a growth pole in the northern area of the city by increasing the size of population between half a million to a million people depending on the 
potentialities of economic development in Damietta Governorate including supplies coming from city of Damietta.

- Extension of network in urban centers serving rural areas at different levels.

(B) Fields of roads and transportation:

- Show interest in providing services and infrastructure so as to provide Preliminaries for integrated society and so that the city becomes a new urban community, not only an industrial or free trade zone area.

- To provide of certain utilities (electricity, water, roads and telecommunications).

(c) Fields of economics:

- Economic development in Damietta is characterized by being a multi-faceted one, Existing and projected activities does have an absolute sovereignty as the development depends on agriculture, trade, industry and crafts.

- Support of complementary activities of the cargo port such as loading and unloading activities, transportation, manufacturing, in order to encourage investment in such complementary activities, including tourist activity, such as the establishment of hotels ,restaurants and complementary tourism services.

- Encouraging activities that serve the free zones in particular industry so as to focus on industrial development in the city in order to achieve added value and lead to the availability of jobs.

- Work to reduce unemployment in the governorate.

- Increased agricultural area by reclaiming more land according to available terrestrial and aquatic resources.

\subsubsection{Industry}

Some of the important axes of industrial strategy are as follows:

- Raise industrial growth rates up to $10 \%$ per year on average.

- Rely on the most intensive employment industries and small industries and light manufacturing.

- Fostering existing industries in the city center, namely, (wood industries - food industries- Mineral \& Engineering).

- Linking the industry to the local market and to the needs of the population and interest in exporting.

\subsubsection{Tourism}

The city has many elements of tourism development, meanwhile optimal exploitation for these elements was not considered concerning beach, archaeological and religious fields, these elements are concentrated in historical sites all over the city, which requires more attention.

\subsubsection{Sectoral investment projects, which can be applied in Damietta}

The Proposed projects, cost of investment and the employment opportunities offered by the development fields are as follow:

\section{a) Investment projects in the agricultural sector:}

Proposed strategy of urban development in the city tries to reflect, what proposed sectoral Strategies calls for i.e., (demographic / social / economic). The Strategy Called for vertical increase of agricultural production and its various activities and for the increase in 
Walaa Abd Al-Razik et al., Towards a sustainable development of Damietta: as a coastal .........

the added value of the city, Strategy of Agricultural expansion of Damietta is one of the priorities. The following are some of those projects:

- A project to inventory and to classify of land.

- A project to improve land.

- A project to develop storage Agricultural Marketing.

- A project to develop seed industry.

- A project for the development and maintenance of waterways.

- A project to re-use of wastewater.

\section{b) Investment projects in the manufacturing sector:}

It was Stress before on the necessity of increasing industrial growth rate to $10 \%$.we also proposed to provide industrial locations in new places such as new city of Damietta. As the Strategy suggested increasing the role of small industries and crafts besides linking industrial development to population, resources, markets and services Projects and others through the following:

- The establishment of ginning, textile and garment factories.

- The establishment of Cereal Mills.

- The establishment of factories for sorting, grading and maintaining of vegetables.

- The establishment of meat processing units.

- Factories for the production of milk products.

- Plants for the production of chemical and plastics industries.

- The establishment of small workshops.

- The establishment of factories for the production of wood products.

- Establish a project to extract salt.

\section{c) Investment projects in the tourism sector}

The tourism sector is considered a neglected sector in Damietta city, and strategy demand the need to pay attention to the tourism sector, through the preserving \& maintaining available resources, and adding new housing capabilities .Also providing with complementary entertainment activities and providing attractive elements of tourism to achieve the integration between both trade and industry by providing the infrastructure needed to raise the efficiency of this sector. Through the following:

- Establish a Project to develop religious shrines and historical areas.

\section{Research results}

The research paper presented a concept for the most important features of sustainable development in the coastal intermediate cities identifying hypotheses of sustainable development plans and reviewing main challenges to be faced and benefits of the eco-city that may affect the sustainable development plans, principles and strategies for sustainable development and its different elements and fields through several research results that appeared as follows:

1. Experiments, which has been applied on intermediate cities Base Plan's found to be applicable on other intermediate cities even despite differences in circumstances of each city, depending on factors like (political, social, geographical legislations and laws issues, financial resources, and economic considerations), it was also found that (General concept, policies, and processing mechanisms \& tools ) could also be applied partially. 
2. The importance of strengthening the role of the cooperative sector and provide all of its requirements so as to enable it playing its role in the effective implementation of social and economic development plans. Moreover, Redesigning of educational policy so as to increase the demand for technical education to fulfill the requirements of the development plans.

3. The importance of giving attention to the development approaches for the city, as an input of sustainable development the city can be based upon, as part of a broader more comprehensive of the sustainable development plan to achieve its objectives.

4. The validity of the hypothesis was proved which was mentioned at forefront of this research which raised the following question "“'Is it possible to achieve a sustainable development of Damietta as coastal intermediate City?"This hypothesis has been validated, in spite of many different approaches to sustainable development of coastal intermediate cities.

\section{Recommendations}

The main recommendations that came out of study:

- Activation of community participation in the development operations of intermediate coastal cities, and increase the degree of social cohesion and cooperation of its inhabitants in preserving the city's resources \& sustainable development besides preservation using publication of Sustainability culture among citizens and also training therm.

- The study recommends taking an action towards establishing of internal marketing centers and exhibitions periodically and to send notifications to consumers of these products and exporters. The study also stressed on keeping the relative importance of each city at the top of the hierarchy of urban centers for each province and work to support the city's role as an influential factor for each province.

- Damiatta city will be able to benefit from its own resources and from resources of other areas which related to it locally, and through its wider regional role framework and to develop of appropriate socio-economic identity for the city, whether it is urban or regional.

- The Study recommends paying attention to planning as an integrated scientifically advanced method which allows in return the identification of industrial development policies of various sectors at the medium and long term, with a good explanation of the policies that define the role of craft industries as an essential pillar to achieve sectoral and regional development Which are balanced with increasing of effectiveness of the local administration to engage the government in advancing the progress of society.

- Preservation of available farmland without urban extension on them by setting controls to prevent the current urban cluster expansion in addition to directing the urban crawl toward non-arable areas and space regions.

\section{REFERENCES}

[1] (Egyptian Arabic: دميـاطDumyāt, IPA: [dom'ja:tc]), also known as Damiata, or Domyat, is a port and the capital of the Damietta Governorate in Egypt).

[2] http://en.wikipedia.org/wiki/Damietta 22-12-2014 
Walaa Abd Al-Razik et al., Towards a sustainable development of Damietta: as a coastal .........

[3]CIMES: (CI +ME +s) means (CIUTATS INTERMEDIES) in Catalan language (used in Spain) which mean Intermediate Cities) in English according to Prof. Josep $\mathrm{M}^{\mathrm{a}}$ Llop Torne, the Director of UIA-CIMES program.

[4] Redclift 1992, p 398.

[5] Foda ,Mohanad Ali,(2013) 'Urban Heritage Sites' Sustainable As an Approach to the Intermediate Cities Development (Applied Study for Mansoura Egypt)". MSC, Architecture Department, Engineering Faculty, Mansoura University, Egypt.

[6] فريق الجهاز التتفبذي لتجديد أحياء القاهرة الإسلامية والفاطمية (2003)،" تحسين الظروف المعيثية من خلال التنمية الحضرية المستـامة في المنـاطق ذات القيمة التاريخية"، المؤتمر العربى الأقليمي، الهيئة العامـة للتخطيط العمراني، القاهرة، 15- 18 نيسمبر 2003.

[7] Goodland Robert, (1987), "Neoclassical Economic and Principles of Sustainable Development", Ecological Modeling, Vol. 38, P.36.

[8]Markandya Anil, (1988), "Natural Environments and the Social Rate of Discount", Project Appraisal, Vol. 3, No. 1, P.11.

[9]Gustave James, (1989), "The Environment: The Greening of Technology Development", Vol. 2, No 3, P. 30-32

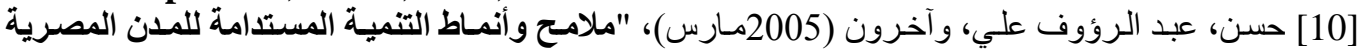

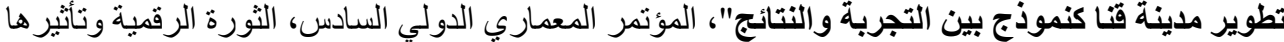

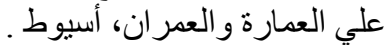

[11]United Cites and Local Governments, "Culture: Fourth Pillar of Sustainable Development".

[12] http://www.uclg.org/en/node/21824

[13] "Sus.Div". Sus.Div. Retrieved 2011-09-28.

[14 ]Agreement between UNESCO and the City of Milan concerning the International Multimedia Institute (IMI) - Appointment of Executive Director - UNESCO Archives ICA AtoM catalogue". Atom.archives.unesco.org. 1999-10-08. Retrieved 2014-01-17.

[15] Liam Magee, Andy Scerri, Paul James, James A. Thom, Lin Padgham, Sarah Hickmott, Hepu Deng, Felicity Cahill (2013). "Reframing social sustainability reporting: Towards an engaged approach". Environment, Development and Sustainability (Springer). doi:10.1007/s10668-012-9384-2.

[16]Tacoli, 1998

[17] United nation report (2002)

[18] UNCHS HABITAT (2001) Cities in a globalization World.Global Report on Human Settlements.Earthscan Publications Ltd London

[19] Rivkin/Rivkin 1982, Rondelli 1993;Euorpan foundation1994

[20] Klaus R.kunzmann, Medium-sized Towns, Strategic Planning and Creative Governance in the South Baltic Arch - Pages 4\& 5

[21] http://en.wikipedia.org/wiki/Coast. 17-1-2012

[22] Same as before

[23] http://www.ecomii.com/dictionary/coastal-zone 23/5/2012

[24 ]ICZM : Integrated Coastal Zone Management

[25] Country Report on Egyptian ICZM Experiences with Special Reference to Sharm El- Sheikh ñ Southern Sinai -2003

[26] Llop, J. M \& Bellet, C (1999)," Intermediate Cities and World Urbanization", UIACIMES work program. 
JES, Assiut University, Faculty of Engineering, Vol. 43, No. 6, November 2015, pp. $882-902$

[27] المخطـط الاسـتر اتيجى العـام لمدينـة دميـاط (2010، الهئيـة العامـة للتخطـيط العمر انسى - وزارة الاسـكان

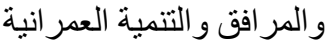

[28] استر اتيجيات التتميـة لمحافظـات الجمهوريـة، (2008)، إقليم الدلتا، محافظة دمياط ، الهئية العامـة للتخطيط

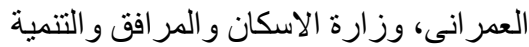

[29] اسـتر اتيجيات التنميـة لمحافظـات الجمهوريـة، (2010)، الهيئة العامـة للتخطيط العمر انسى ، وزارة الاسكان

[30] http://en.wikipedia.org/wiki/Damietta (29-01-2015) و المر افق العامة.

[31] http://163.121.56.10/NEW/cities/domyat/domyat.html2015-02-01

[32]Preliminary results of the General Census of Population and Housing and constructions, Central Agency for Public Mobilization and Statistics 2006

[33] Josep Mair LIOP 1999

[34] http://en.wikipedia.org/wiki/Damietta ( 29-01-2015)

[35] http://iskandrany.6te.net/distances.htm 02-01-2015

[36] http://en.wikipedia.org/wiki/Mansoura,_Egypt 01-02-2015

[37] http://iskandrany.6te.net/distances.htm 02-01-2015

[38] http://en.wikipedia.org/wiki/Cairo 01-02-2015

[39] General plan for the city Damietta.

[40] Josep Mair LIOP 1999

[41] http://163.121.56.10/NEW/cities/domyat/domyat.html2015-02-01

[42] EHDR ,2003,page 23

[43] http://en.wikipedia.org/wiki/Egypt 29-01-2015

[44] Strategic Planned and general outline of the city of Damietta 2014

[45] http://www.investment.gov.eg/ar/EgyptMap/Pages/DamiettaAbout.aspx 01-02-2015

[46] http://163.121.56.10/NEW/cities/domyat/domyat.html2015-02-01

[47] http://www.mts.gov.eg

[48] http://www.almasryalyoum.com/news/details/603356 01-02-2015

[49] http://www.almasryalyoum.com/news/details/603356 01-02-2015

[50 ] The General Plan of the city of Damietta . 

نحو تنمية مستدامة لامياط كمدينة متوسطة ساحلية فى مصر : نمر

\section{(الملخص:}

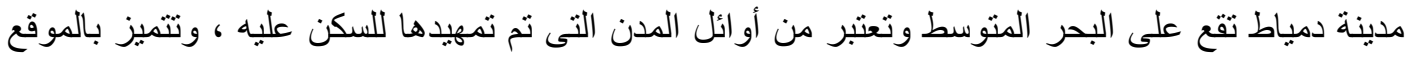

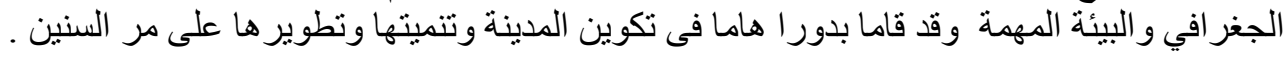

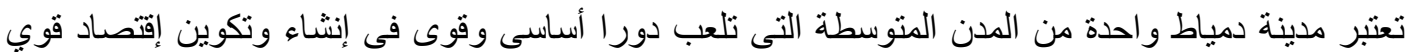

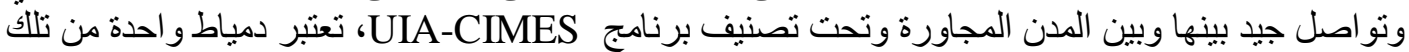
الدن التى لها تأثير قوى لمثل البيئة الساحلية والقيمة الإقتصادية و إيضا العمق التاريخي لمدينة مثل مدينة دمياط.

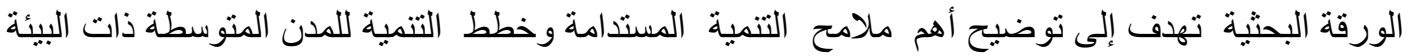

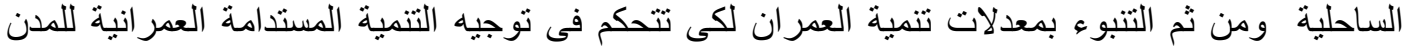

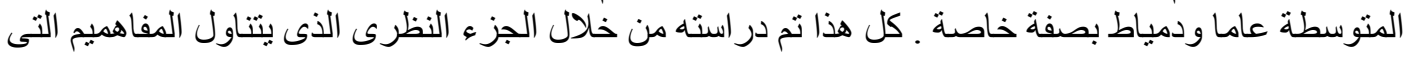

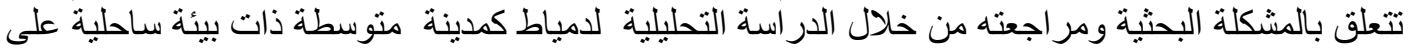
البحر المتوسط، من ثم تحليل النتائج

الكلمات الدفتاحية: المدن المتوسطة ـ الددن المستدامة ـ التنمية المستدامة ـ المدن الساحلية ـدمياط 